\title{
Benefiting from Listening in Vocabulary Development
}

\author{
Berker Bulut $^{1}$, Nuri Karasakaloğlu ${ }^{1}$ \\ ${ }^{1}$ Faculty of Education, Adnan Menderes University, Aydın, Turkey \\ Correspondence: Berker Bulut, Faculty of Education, Adnan Menderes University, Aydın, Turkey.
}

Received: October 8, 2017

Accepted: October 29, 2017 Online Published: November 21, 2017

doi:10.11114/jets.v5i12.2688

URL: https://doi.org/10.11114/jets.v5i12.2688

\begin{abstract}
In this research, the effect of active listening training given to fourth grade students on their vocabulary was examined. Pre-test - post-test control group trial model, which is one of the semi-experimental trial models, was used. Besides, "Vocabulary Test" developed by the researcher was applied to experimental and control groups before the experimental implementations. The students in the experimental group were given a weekly two-hour-course of active listening training for eight weeks. The students in the control group were provided the materials forming the content of active listening training but they were made to study these materials with a weekly two-hour-course by traditional listening practice for eight weeks. At the end of the experiment, the test introduced as pre-test was also used as post-test in order to assess the differences between the groups. As the findings obtained from the research were analyzed, it was seen that active listening training positively contributed to vocabulary development levels of fourth grade students. Together with this, the other conclusion obtained from the research was that the students' listening comprehension achievement contributed to learning new words.
\end{abstract}

Keywords: vocabulary, listening, active listening training

\section{Introduction}

Language is a tool that is used to express and acquire feelings, thoughts, attitudes and beliefs, and to convey the information about the events perceived and experienced, and the accumulation of culture. In short, with the most general definition, language is a communication tool. Özbay (2005) expresses that with the use of language, communication and interaction based on words and writings have begun between people.

It is seen that language teaching has a great importance when the place of language in the individual's life and that of the society is taken into consideration. Karakuş (2002) also states that language should be taught in an accurate, thorough and widespread manner.

The goals set for all stages of teaching the native language are aimed at acquiring language skills related to comprehension and narration in general. It should be aimed to develop such basic language skills as listening, speaking, reading and writing in a balance in native language teaching because in the language development process, these learning areas have been interacting and completing each other. Sever (2011) shows this relationship in the following way:

\footnotetext{
"This study is generated from the master's thesis titled "The Effect of Active Listening Training on Listening Comprehension, Reading Comprehension and Vocabulary" prepared by Berker BULUT by the supervision of the second writer.
} 


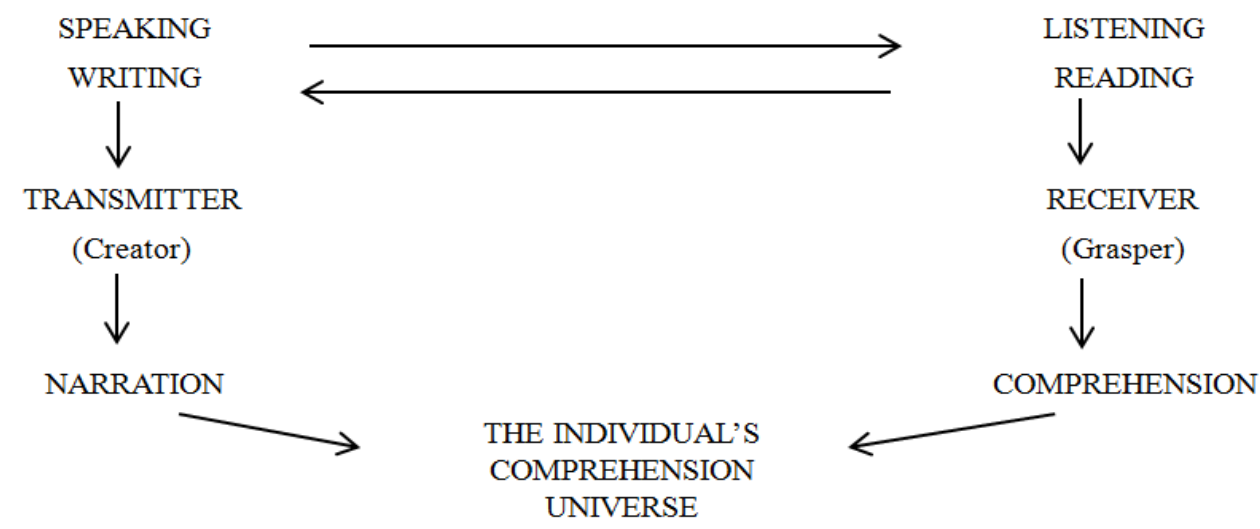

Figure 1. The Domains of Native Language Teaching

As can be understood from the chart, the individual's comprehension universe is formed as a result of the interaction of listening, speaking, reading and writing. Listening and reading skills are in the comprehension dimension, and speaking and writing skills are in the narration dimension. While the individual is in the "receiver" of incoming messages role in the comprehension process, the individual is in the "transmitter" role in conveying emotions and thoughts as a whole in the narration process.

In the general aims stated in the Turkish curriculum (2009), in addition to improving the students' listening, speaking, reading, writing, visual reading and visual presentation skills, it is also included to ensure that the students love Turkish and use it correctly, beautifully and effectively. This can only be achieved by enriching the vocabulary of the students and developing their universe of emotions and thoughts. Individuals with rich vocabulary can express their feelings and thoughts appropriately for their purpose both verbally or in writing, as well as fully and correctly understanding what they watch, listen and read.

The listening discussed in this study is defined as a psychological process which begins with the awareness and attention to the sounds and images, continues with the recognition of certain auditory signs, and which ends with the recognition of these signs (Ergin \& Birol, 2000). It is known that the individual is in an effort to understand what is going on around him or her by using his/her listening skill from the first moment he/she was born. The individual can improve vocabulary by using listening skill as much as the vocabulary owned by nearby family surroundings. Vocabulary is defined as all the words that people acquire in proportion to their age, gender, natural and social environment (Koçak, 1999). The ability of the individual to actively use the four basic language skills with the acquisition of these skills is closely related to the acquired, rich vocabulary. As a matter of fact, knowing plenty of vocabulary will contribute to the individuals' comprehension of what they read and listen, and it will make important contributions for them to be able to tell what they feel and think both verbally or in writing (Güleryüz, 1998).

The first words related to the mother tongue begin to be formed through listening. As speaking, reading and writing skills begin to be used later on, the richness in vocabulary also begins to increase. Listening is an effective way of learning the words that the student has not encountered before, when encountered whether accidentally or deliberately. Listening a presentation, a discussion, a reading text, a song, etc. on any subject increases the likelihood of encountering different words and contributes to the enrichment of the individual's vocabulary (Temur, 2006).

According to Tosunoğlu (1999), the child who learns new words by listening realizes speaking in this way. Within this context, it is thought to be important to develop vocabulary that helps the individuals to use their comprehension and narration skills more effectively.

In this research, listening training was used to improve the vocabulary of the fourth grade students.

\subsection{The Purpose of the Research}

The purpose of this research is to reveal the effect of active listening training given to fourth grade students on their vocabulary.

In order to achieve this aim, the following hypotheses were tested:

1. The change in the pre-test - post-test "vocabulary test" scores of the students in the experimental group in which active listening training was given and the students in the control group in which this training was not given shows a significant difference on behalf of the experimental group.

2. The change in post-test "vocabulary test" scores of the students in the experimental group in which active listening training was given explains the post-test scores of "listening comprehension test" significantly. 


\section{Method}

\subsection{Research Model}

This research was designed in experimental trial model as it was aimed to analyze the effect of active listening training given to fourth grade students on their vocabulary. As noted by Gay, Mills and Airasian (2005), the difficulty in assigning students into groups in an unbiased manner in educational environments leads researchers to use semi-experimental design in which available groups can be matched over certain variables and unbiased assignments can be made over these groups. In this study, pre-test - post-test control group trial model, which is one of the semi-experimental trial models, was used as it was not possible to randomly rearrange the students studying in the fourth grades of the schools determined. In this model, the researcher assigns one of the existing groups as the experimental group and the other as the control group, and applies the pre-tests to both of the groups. After the experimental activities carried out in the experimental group, the researchers apply the post-tests again to both of the two groups and compares the differences between them.

In the research, "Vocabulary Test" developed by the researcher before experimental applications was applied to test and control groups. The students in the experimental group were given active listening training for eight weeks totally, two hours per week. The students in the control group were given the materials that form the content of active listening training but they were made to deal with these materials through traditional listening exercises for eight weeks totally, two hours of practice per week. At the end of the applications, the tests presented as pre-tests were given as post-tests this time to assess the differences between the groups. In addition to this, at the end of the research, "Listening Comprehension Test" developed by the researcher was applied in order to determine whether the change in the students' vocabulary achievements was affected by their listening comprehension achievements.

Table 1. Experimental Model Used in the Research

\begin{tabular}{|c|c|c|c|c|}
\hline & $\mathbf{N}$ & Pre-test & Application Process & Post-test \\
\hline Test & 62 & Vocabulary Test & Active Listening Training & $\begin{array}{c}\text { Vocabulary Test } \\
\text { Listening Comprehension Test }\end{array}$ \\
\hline Control & 63 & Vocabulary Test & Traditional Listening Exercises & Vocabulary Test \\
\hline
\end{tabular}

The research was conducted on a total of 125 fourth grade students with a moderate socio-economic levels studying at two state schools in the central district of Aydin city. The schools where the research were conducted were determined on a voluntary basis. In accordance with the official permissions from the City Governance and Provincial Directorate of National Education, the two schools were visited and the administration of the school and fourth-grade teachers were interviewed. As the two schools were seen to have similar structures as a result of the interviews, they were determined as the sample of the study. In forming the test and control groups, the lottery method was used with the approval of the school administration and the teachers. Selecting the test and control groups from different schools is important in terms of the fact that the students having active listening training and those not having such a training are not affected from each other. It was also intended to increase external validity by providing the participation of all the fourth grade students at the school where active listening training was given, by giving the training activities to the students in the same school via the same method and by treating the groups with the feeling that they are within the scope of the research and preventing unusual responses. On the other hand, groups were compared in terms of their qualities in order to analyze the equivalence of the schools. For this purpose, in accordance with the data obtained from the Turkish Statistical Institute (TUIK), the development levels of the two schools were determined. Accordingly, it can be said that the schools have moderate socio-economic levels. In terms of overall success levels, it was confirmed by the school administrators and class teachers that there was no difference between the two schools.

In addition, the results of the pre-tests applied were compared so as to determine the pre-application status of the test and control groups. For this, Kolmogorov-Smirnov test results of the two groups were analyzed at first in order to determine whether they were normally distributed or not. Accordingly, it can be said that "Vocabulary Test" pre-test (Kolmogorov-Smirnov $\mathrm{Z}=0.774, \mathrm{p}>.05$ ) mean scores of the experimental group and "Vocabulary Test" pre-test (Kolmogorov-Smirnov $Z=0.666, p>.05$ ) mean scores of the control group meets the normality assumption. In order to determine whether there was a significant difference between the pre-test mean scores of test and control groups, Independent Samples T-Test was performed.

Table 2. The Comparison of Experimental and Control Groups According to their Pre-test Results

\begin{tabular}{cccccccc}
\hline Pre-test & Groups & $\mathbf{N}$ & & $\overline{\mathbf{X}}$ & df & t & p \\
\hline Vocabulary Test & Test & 62 & 60.67 & 18.26 & \multirow{2}{*}{123} & \multirow{2}{*}{0.19} & \multirow{2}{*}{.848} \\
\hline Vocabulary Test & Control & 63 & 60.09 & 15.56 & & & \\
\hline
\end{tabular}


As seen in the table, it was found that there was no significant difference between the Vocabulary Test $[\mathrm{t}(123)=0.19$, $\mathrm{p}>.05]$ mean scores of test and control groups. Based on these findings, it can be said that the students in the test and control groups are equivalent in terms of the dependent variable of the research.

\subsection{Data Collection Tools}

\subsubsection{Vocabulary Test}

Within the scope of the research, "Vocabulary Test" was used in order to determine the students' vocabulary achievements. The test was developed by the researcher, using similar vocabulary tests obtained after literature review. The preparation of the test was carried out by means of the following steps.

1. In the preparation process of the test, a question pool of 85 items was formed in accordance with the acquisitions related with the development of the fourth grade vocabulary in the Primary Education (Grades 1-5) Turkish Curriculum.

2. The items in the question pool formed were analyzed by two class teachers who work in primary schools and one academician each who is in Elementary Education Department, Measurement and Evaluation in Education. The items which were not found appropriate for test and assessment criterions and for the level of the student were removed from the test and some necessary corrections were made on some items. As a result, a total of 80-item-trial-form was prepared. However, taking into account that students may be bored while answering the questions and that the test duration is longer than a lesson hour, the 80 questions in the test was divided into two forms as $\mathrm{A}$ and $\mathrm{B}$, with 40 questions each.

3. Trial forms divided as form A and form B were applied to a total of 226 students on different days who were studying in the fourth class of seven different schools having similar characteristics with the schools where the applications would be performed.

4. After the trial practices, item and test analyzes were performed. As a result of the statistical procedures for the item analysis, the difficulty index $(\mathrm{Pj})$, standard deviation $(\mathrm{Sj})$ and discriminant index (rpbi) values of the items in the test were calculated. Items with a discrimination index (rpbi) of less than .30 were eliminated. Besides, items with an item difficulty index $(\mathrm{Pj})$ of less than .10 and more than .90 were also removed from the test. As a result of these analyzes, the Vocabulary Test consisting of 50 items was prepared.

5. The t-test results for the difficulty index $(\mathrm{Pj})$, standard deviation $(\mathrm{Sj})$ and discriminant index (rpbi) values of the final form of the test items and the lower and upper $27 \%$ groups are given in the table below.

Table 3. Item Analysis Results of the Vocabulary Test

\begin{tabular}{cccccccccccc}
\hline Item Number & $\mathbf{P j}$ & $\mathbf{S j}$ & $\mathbf{r}_{\mathbf{p b i}}$ & $\mathbf{t}$ & $\mathbf{p}$ & $\mathbf{I t e m} \mathbf{N u m b e r}$ & $\mathbf{P j}$ & $\mathbf{S j}$ & $\mathbf{r}_{\mathbf{p b i}}$ & $\mathbf{T}$ & $\mathbf{p}$ \\
\hline $\mathbf{2}$ & .68 & .46 & .48 & 11.09 & .000 & $\mathbf{3 2}$ & .72 & .44 & .63 & -3.56 & .000 \\
$\mathbf{3}$ & .65 & .47 & .62 & 14.19 & .000 & $\mathbf{3 4}$ & .35 & .47 & .55 & 12.20 & .000 \\
$\mathbf{4}$ & .85 & .34 & .42 & 5.41 & .000 & $\mathbf{3 5}$ & .55 & .49 & .60 & 15.73 & .000 \\
$\mathbf{5}$ & .84 & .35 & .54 & 7.62 & .000 & $\mathbf{3 6}$ & .59 & .49 & .50 & 10.46 & .000 \\
$\mathbf{6}$ & .88 & .31 & .51 & 5.81 & .000 & $\mathbf{3 9}$ & .32 & .47 & .43 & 8.22 & .000 \\
$\mathbf{8}$ & .91 & .28 & .46 & 4.61 & .000 & $\mathbf{4 1}$ & .72 & .44 & .39 & 5.47 & .000 \\
$\mathbf{1 0}$ & .85 & .34 & .48 & 6.23 & .000 & $\mathbf{4 3}$ & .76 & .42 & .45 & 6.70 & .000 \\
$\mathbf{1 1}$ & .58 & .49 & .54 & 13.08 & .000 & $\mathbf{4 5}$ & .86 & .34 & .47 & 6.23 & .000 \\
$\mathbf{1 2}$ & .69 & .46 & .55 & 10.69 & .000 & $\mathbf{4 8}$ & .91 & .28 & .41 & 5.01 & .000 \\
$\mathbf{1 3}$ & .61 & .48 & .66 & 19.39 & .000 & $\mathbf{4 9}$ & .76 & .42 & .44 & 6.32 & .000 \\
$\mathbf{1 4}$ & .66 & .47 & .58 & 15.65 & .000 & $\mathbf{5 0}$ & .78 & .40 & .45 & 7.62 & .000 \\
$\mathbf{1 6}$ & .78 & .40 & .49 & 7.26 & .000 & $\mathbf{5 3}$ & .59 & .49 & .49 & 11.97 & .000 \\
$\mathbf{1 8}$ & .27 & .44 & .41 & 8.40 & .000 & $\mathbf{5 4}$ & .73 & .44 & .29 & 6.23 & .000 \\
$\mathbf{1 9}$ & .39 & .49 & .36 & 7.38 & .000 & $\mathbf{5 6}$ & .23 & .42 & .32 & 4.92 & .000 \\
$\mathbf{2 0}$ & .44 & .49 & .37 & 7.41 & .000 & $\mathbf{5 8}$ & .41 & .49 & .46 & 8.05 & .000 \\
$\mathbf{2 1}$ & .77 & .41 & .49 & 8.40 & .000 & $\mathbf{6 0}$ & .25 & .43 & .39 & 5.90 & .000 \\
$\mathbf{2 2}$ & .19 & .39 & .31 & 5.41 & .000 & $\mathbf{6 2}$ & .18 & .38 & .34 & 5.79 & .000 \\
$\mathbf{2 3}$ & .16 & .37 & .33 & 5.21 & .000 & $\mathbf{7 0}$ & .67 & .47 & .32 & 6.14 & .000 \\
$\mathbf{2 4}$ & .18 & .38 & .37 & 5.58 & .000 & $\mathbf{7 1}$ & .64 & .47 & .65 & 14.60 & .000 \\
$\mathbf{2 5}$ & .18 & .38 & .41 & 6.90 & .000 & $\mathbf{7 2}$ & .76 & .42 & .50 & 7.87 & .000 \\
$\mathbf{2 7}$ & .80 & .39 & .47 & 6.90 & .000 & $\mathbf{7 3}$ & .66 & .47 & .50 & 8.37 & .000 \\
$\mathbf{2 8}$ & .59 & .49 & .36 & 5.44 & .000 & $\mathbf{7 4}$ & .41 & .49 & .46 & 7.06 & .000 \\
$\mathbf{2 9}$ & .83 & .37 & .53 & 6.46 & .000 & $\mathbf{7 7}$ & .33 & .47 & .55 & 12.20 & .000 \\
$\mathbf{3 0}$ & .86 & .34 & .42 & 5.41 & .000 & $\mathbf{7 9}$ & .61 & .48 & .55 & 11.09 & .000 \\
$\mathbf{3 1}$ & .63 & .48 & .44 & 7.36 & .000 & $\mathbf{8 0}$ & .24 & .43 & .31 & 5.05 & .000 \\
\hline & & & & & & & & & & \\
\hline
\end{tabular}


When the table is analyzed, it can be seen that the discriminant power of the 50 items remaining after the items that do not meet the necessary requirements

(1-7-9-15-17-26-33-37-38-40-42-44-46-47-51-52-55-57-59-61-63-64-65-66-67-68-69-75-76-78) were removed from the test varied between .29 and .66 and that $t$ value calculated for the lower and upper $27 \%$ groups is significant $(\mathrm{p}<.001)$. In addition to this, the item numbered 54 with a discriminant index (rpbi) of .298 was determined to be included in the test as it was utterly close to .30 . These results can be interpreted as that the validity of the items in the test is high and they can distinguish students in terms of vocabulary achievement.

The results of the test analysis performed after the item analysis are shown in the following table.

Table 4. Test Analysis Results of the Vocabulary Test

\begin{tabular}{cccccccc}
\hline $\begin{array}{c}\text { Total } \\
\text { Number } \\
\text { of Items }\end{array}$ & $\mathbf{N}$ & $\overline{\mathbf{X}}$ & SD & Mode & Median & $\begin{array}{c}\text { Mean } \\
\text { Difficulty }\end{array}$ & KR-20 \\
\hline 50 & 226 & 29.58 & 10.76 & 39 & 32 & .59 & .93 \\
\hline
\end{tabular}

When Table 4 is analyzed, it is seen that the mean difficulty of the test scores is .59. This value can be interpreted as that the test is of moderate difficulty and thus a desirable test. In the findings related with the reliability of the test, KR-20 value was calculated as .93. This result shows that the test scores are reliable and that the achievement test can be used in this research.

\subsubsection{Listening Comprehension Test}

In order to measure the achievement of the students' listening comprehension, the "Listening Comprehension Test" was developed by the researcher. While the test was being prepared, the test went through the following steps.

1. First of all, in accordance with the aim of the research, the measurable ones among the 33 acquisitions related to the listening comprehension about the fourth grade listening learning field was selected. For this purpose, four academicians each from Curriculum and Instruction, Measurement and Evaluation in Education, Turkish Education and Elementary Education Departments were interviewed and their ideas about the subject were gathered. In the light of the opinions of the experts, of the acquisitions serving for a similar purpose, the appropriate one was chosen and the ones that could not be assessed in the testing process were not put into practice. As a result of the assessments made, it was concluded that of the listening comprehension acquisitions, 15 acquisitions had measurable characteristics.

2. Takin into account the acquisitions determined, questions in terms of each acquisition were included to be able to provide the content validity and a question pool of totally 50 items was formed. The items prepared were analyzed by two class teachers who work in primary schools and one academician each who is in Classroom Teaching Department, Test and Assessment in Education. The items which were not found appropriate were removed from the test and some necessary corrections were made on some items. As a result, a total of 46-item-trial-form was prepared.

3. The trial form was applied to a total of 218 students studying at the fourth grade of five schools with similar characteristics to the schools in which the application would be implemented. The students were asked to answer all questions seriously, to express the questions they had difficulty in understanding, and they were given enough time to answer.

4. After the trial practices, item and test analyzes were performed. As a result of the statistical procedures for the item analysis, the difficulty index $(\mathrm{Pj})$, standard deviation $(\mathrm{Sj})$ and discriminant index (rpbi) values of the items in the test were calculated. Items with a discrimination index (rpbi) of less than .30 were eliminated. Besides, items with an item difficulty index $(\mathrm{Pj})$ of less than .10 and more than .90 were also removed from the test. As a result of these analyzes, the Listening Comprehension Test consisting of 35 items was prepared.

5. The t-test results for the difficulty index $(\mathrm{Pj})$, standard deviation $(\mathrm{Sj})$ and discriminant index (rpbi) values of the final form of the test items and the lower and upper $27 \%$ groups are given in Table 5 below. 
Table 5. Item Analysis Results of the Listening Comprehension Test

\begin{tabular}{|c|c|c|c|c|c|c|c|c|c|c|c|}
\hline $\begin{array}{c}\text { Item } \\
\text { Number }\end{array}$ & $\mathbf{P j}$ & $\mathbf{S j}$ & $\mathbf{r}_{\mathrm{pbi}}$ & $\mathbf{t}$ & $\mathbf{p}$ & $\begin{array}{c}\text { Item } \\
\text { Number }\end{array}$ & $\mathbf{P j}$ & $\mathbf{S j}$ & $\mathbf{r}_{\mathbf{p b i}}$ & $\mathbf{t}$ & p \\
\hline 1 & .86 & .34 & .43 & 6.30 & .000 & 28 & .86 & .34 & .45 & 5.87 & .000 \\
\hline 2 & .73 & .44 & .36 & 7.50 & .000 & 29 & .84 & .36 & .45 & 6.53 & .000 \\
\hline 3 & .72 & .44 & .39 & 7.25 & .000 & 30 & .81 & .38 & .45 & 6.53 & .000 \\
\hline 9 & .72 & .44 & .35 & 6.52 & .000 & 31 & .79 & .40 & .42 & 6.53 & .000 \\
\hline 10 & .86 & .34 & .39 & 5.45 & .000 & 32 & .66 & .47 & .45 & 8.13 & .000 \\
\hline 11 & .41 & .49 & .74 & 40.65 & .000 & 33 & .71 & .45 & .45 & 7.57 & .000 \\
\hline 12 & .50 & .50 & .61 & 13.16 & .000 & 34 & .64 & .48 & .51 & 11.05 & .000 \\
\hline 13 & .47 & .50 & .67 & 17.95 & .000 & 35 & .65 & .47 & .50 & 11.05 & .000 \\
\hline 14 & .53 & .50 & .54 & 14.04 & .000 & 36 & .50 & .50 & .50 & 11.07 & .000 \\
\hline 15 & .77 & .42 & .39 & 6.99 & .000 & 37 & .54 & .50 & .50 & 11.71 & .000 \\
\hline 17 & .68 & .46 & .46 & 9.28 & .000 & 38 & .78 & .40 & .38 & 6.99 & .000 \\
\hline 19 & .88 & .31 & .39 & 5.04 & .000 & 39 & .83 & .37 & .43 & 6.76 & .000 \\
\hline 20 & .70 & .45 & .41 & 8.64 & .000 & 40 & .77 & .41 & .43 & 7.04 & .000 \\
\hline 21 & .44 & .49 & .64 & 19.22 & .000 & 42 & .48 & .50 & .44 & 10.41 & .000 \\
\hline 22 & .77 & .41 & .45 & 6.76 & .000 & 44 & .55 & .49 & .48 & 10.41 & .000 \\
\hline 25 & .33 & .47 & .56 & 10.94 & .000 & 45 & .69 & .46 & .51 & 10.63 & .000 \\
\hline 26 & .80 & .39 & .48 & 7.48 & .000 & 46 & .50 & .50 & .51 & 12.55 & .000 \\
\hline 27 & .87 & .33 & .46 & 6.76 & .000 & & & & & & \\
\hline
\end{tabular}

When the table is analyzed, it can be seen that the discriminant power of the 35 items remaining after the items whose discriminant indexes (rpbi) was less than .30 (4-5-6-7-8-16-18-23-24-41-43) were removed from the test varied between .35 and .74 and that $t$ value calculated for the lower and upper $27 \%$ groups is significant $(p<.001)$. These results can be interpreted as that the validity of the items in the test is high and they can distinguish students in terms of listening comprehension achievement.

The results of the test analysis performed after the item analysis are shown in Table 6.

Table 6. Test Analysis Results of Listening Comprehension Test

\begin{tabular}{cccccccr}
\hline $\begin{array}{c}\text { Total } \\
\text { Number } \\
\text { of Items }\end{array}$ & $\mathbf{N}$ & $\overline{\mathbf{X}}$ & SD & Mode & Median & Mean Difficulty & KR-20 \\
\hline 35 & 218 & 23.82 & 8.06 & 35 & 22 & .68 & .92 \\
\hline
\end{tabular}

When the table is analyzed, it is seen that the mean difficulty of the test scores is .68. This value can be interpreted as that the test is of moderate difficulty and thus a desirable test. In the findings related with the reliability of the test, KR-20 value was calculated as .92. Accordingly, it can be interpreted that the test scores are reliable and that the achievement test can be used in this research.

\subsection{Data Collection}

Before the application, the vocabulary test developed by the researcher was applied as the pre-test to determine the condition of the experimental group and the control group in terms of the dependent variable (vocabulary) of the study. After the test and control groups were identified, the students in the experimental group and the class teachers were provided with the necessary explanations about the content of active listening training before their applications and their awareness about the training was raised.

The students in the experimental group were given active listening training for eight weeks, two lessons per week within the scope of Turkish lesson. A total of 16 hours of training was performed in eight sessions. The total duration of each session was two lesson hours. Throughout the training, students watched videos of everyday life as well as listening to texts appropriate to their levels, and all these were conducted according to the process steps of active listening training. Two informative texts, two narrative texts, a poem and a video were used in the research. The texts included in the scope of the research were selected from books suitable for the levels of the fourth and fifth grade students that were approved by the Board of Education in accordance with the Elementary Turkish Program. The reason for using texts also from fifth grade books in spite of the fact that the study group is composed of fourth grade students was the assumption that it is also possible for the students to listen to the texts higher than their levels. Trelease (1989, cited by Schwartz, 1995) also states that a student at the fourth grade level can listen to books up to the fifth or sixth grade levels. On the other hand, the reason for selecting different text types in the application was to provide the students to shape their listening intentions. In addition, in order to avoid the inconveniences that might arise from the accents during the reading of the texts, the texts used in the application process were vocalized and recorded. The students listened to these texts from these records during the application. 
In the research, the use of video was considered appropriate taking into account the fact that audiovisual tools facilitate learning and remembrance. Doğan (2011) also states that using only literary texts in the studies about listening skill is not enough, and emphasizes that using both visual and auditory training materials in addition to texts will provide higher effectiveness. The video used was selected from a short film prepared by the TRT School on a topic in the fourth grade textbook which was approved by the Board of Education.

The students in the control group were also provided with materials that constitute the content of active listening training, but they were made to study these materials by class teachers for eight weeks with two hours of practice per week, performing traditional listening exercises such as note taking and questions asked by the teacher after listening.

At the end of the experimental process, the Vocabulary Test and Listening Comprehension Test were given as the post-test to test and control groups.

The weekly distribution of the training conducted for the experimental group in the research is shown in the table below.

Table 7. The Weekly Distribution of Active Listening Training

\begin{tabular}{|c|c|c|}
\hline & 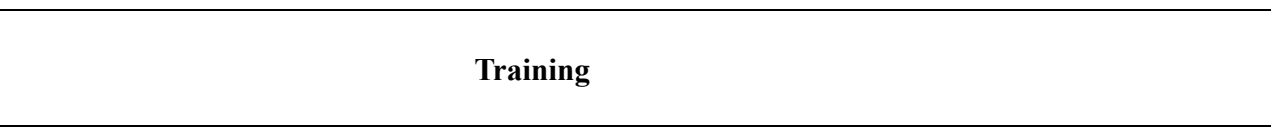 & $\begin{array}{l}\text { Lesson Hour } \\
\text { Duration } \\
(40 \text { minutes) }\end{array}$ \\
\hline \multirow[b]{2}{*}{$\begin{array}{c}1 . \\
\text { Session }\end{array}$} & - $\quad$ The Definition of Active Listening & 1 \\
\hline & $\begin{array}{l}\text { Understanding the differences between listening and hearing and introducing active listening } \\
\text { behaviors } \\
\text { - The Acquisitions of Active Listening } \\
\text { Gaining information about the importance of listening in interpersonal relations and learning }\end{array}$ & 1 \\
\hline \multirow[b]{2}{*}{$\begin{array}{c}2 . \\
\text { Session }\end{array}$} & - The Characteristics of Listening Types & 1 \\
\hline & $\begin{array}{l}\text { Introducing various listening types related with the subject to be listened and appropriate for the } \\
\text { determined objective, and giving information about the characteristics of them. } \\
\text { - How to Listen More Effectively? } \\
\text { Presenting examples of activities to improve listening skills and providing information practically. }\end{array}$ & 1 \\
\hline \multirow[b]{4}{*}{$\begin{array}{c}4 . \\
\text { Session }\end{array}$} & - $\quad$ Listening Type: Discriminant Listening & 1 \\
\hline & $\begin{array}{l}\text { Studying the narrative text titled "Atatürk's High Sense of Humanity (Atatürk'ün Yüksek İnsanlık } \\
\text { Duygusu)" appropriate for the purpose of discriminant listening and performing activities in } \\
\text { accordance with the process steps of active listening method }\end{array}$ & 1 \\
\hline & - $\quad$ Listening Type: Discriminant Listening & 1 \\
\hline & $\begin{array}{l}\text { Studying the poem titled "The Carpenter (Marangoz)" appropriate for the purpose of discriminant } \\
\text { listening and performing activities in accordance with the process steps of active listening method }\end{array}$ & 1 \\
\hline \multirow[b]{2}{*}{$\begin{array}{c}5 . \\
\text { Session }\end{array}$} & - $\quad$ Listening Type: Listening for Information & 1 \\
\hline & $\begin{array}{l}\text { Studying the informative text titled "The Voice of Our Heart (Kalbimizin Sesi)" appropriate for the } \\
\text { purpose of listening for information and performing activities in accordance with the process steps } \\
\text { of active listening method }\end{array}$ & 1 \\
\hline \multirow[b]{2}{*}{$\begin{array}{c}6 . \\
\text { Session }\end{array}$} & - $\quad$ Listening Type: Empathetic Listening & 1 \\
\hline & $\begin{array}{l}\text { Studying the informative text titled "Golden Advices (Altın Öğ̈̈tler)" appropriate for the purpose } \\
\text { of empathetic listening and performing activities in accordance with the process steps of active } \\
\text { listening method }\end{array}$ & 1 \\
\hline \multirow[b]{2}{*}{$\begin{array}{c}7 . \\
\text { Session }\end{array}$} & • $\quad$ Listening Type: Critical Listening & 1 \\
\hline & $\begin{array}{l}\text { Studying the narrative text titled "Festivals in My Childhood (Çocukluğumdaki Bayramlar)" } \\
\text { appropriate for the purpose of critical listening and performing activities in accordance with the } \\
\text { process steps of active listening method }\end{array}$ & 1 \\
\hline \multirow[b]{2}{*}{$\begin{array}{c}8 . \\
\text { Session }\end{array}$} & - $\quad$ Listening Type: Aesthetic Listening & 1 \\
\hline & $\begin{array}{l}\text { Studying the short film titled "The First Flying Man (Uçan İlk İnsan)" appropriate for the purpose } \\
\text { of aesthetic listening and performing activities in accordance with the process steps of active } \\
\text { listening method }\end{array}$ & 1 \\
\hline
\end{tabular}

Whether the scores the groups obtained from pre-tests and post-tests showed normal distribution was analyzed by the Kolmogorov-Smirnov test.

In order to determine whether the groups' pre-test mean scores differed from each other, Independent Samples T-Test was used.

In order to determine whether the changes observed in the pretest - post-test mean scores of the groups differed from each other, Two-Way ANOVA for Mixed Measures was used. Two-Way ANOVA analysis for one factor repeated 
measures is an analysis that is frequently used in the analysis of the data collected in split-pilot designs in which experimental studies are performed (Büyüköztürk, 2011)

Simple Linear Regression analysis was used so as to determine whether the changes in the vocabulary achievements, which is the dependent variable of the research, of the students in the experimental group were due to the increase in their listening comprehension achievements depending on active listening training given.

\section{Findings}

The findings obtained from the analysis of the collected data were arranged and interpreted according to the hypotheses of the research.

The first hypothesis of the study was stated as "The change in the pre-test - post-test "vocabulary test" scores of the students in the experimental group in which active listening training was given and the students in the control group in which this training was not given shows a significant difference on behalf of the experimental group".

ANOVA (Variance Analysis) was used in testing the research hypothesis. First of all, it was analyzed whether the assumptions of the variance analysis were met or not. Accordingly, whether the normality assumptions regarding the vocabulary test of pre-test and post-test scores of experimental group and control group was met or not was tested with the Kolmogorov-Smirnov test. It can be said that the "Vocabulary Test" pre-test (Kolmogorov-Smirnov Z $=0.774$, $p>.05$ ) and post-test (Kolmogorov-Smirnov $Z=0.828, p>.05$ ) mean scores of the experimental group showed normal distribution. Similarly, it can be said that the "Vocabulary Test" pre-test (Kolmogorov-Smirnov Z $=0.666, p>.05$ ) and post-test (Kolmogorov-Smirnov $Z=0.862, \mathrm{p}>.05$ ) mean scores of the control group also showed normal distribution. On the other hand, the variance of the scores the groups obtained from the pre-test and post-test should be equal. According to the Levene test result, it was determined that the variance of the "Vocabulary Test" pre-test total scores [F $(1,123)=1.68, p>.05]$ and of the "Vocabulary Test" post-test total scores $[F(1,123)=3.64, p>.05]$ were homogeneous. These findings proved that the equality of the variances assumption was met.

The arithmetic mean and standard deviation values of the "Vocabulary Test" pre-test - post-test scores of the students in the experimental group and control group in which the study was conducted are given in the table below.

Table 8. Mean Value and Standard Deviation Value of the Vocabulary Test

\begin{tabular}{|c|c|c|c|c|c|c|}
\hline \multirow{2}{*}{ GROUPS } & \multicolumn{3}{|c|}{ PRE-TEST } & \multicolumn{3}{|c|}{ POST-TEST } \\
\hline & $\mathbf{N}$ & $\overline{\mathbf{X}}$ & SD & $\mathbf{N}$ & $\overline{\mathbf{X}}$ & SD \\
\hline Test & 62 & 60.67 & 18.26 & 62 & 70.22 & 19.68 \\
\hline Control & 63 & 60.09 & 15.56 & 63 & 61.92 & 15.99 \\
\hline
\end{tabular}

When the table is analyzed, it can be seen that while the mean score of the students in the experimental group was 60.67 in pre-test, this value was 70.22 after the experimental process was applied. The mean score of the students in the control group was 60.09 in pre-test and 61.92 in post-test. According to this, it can be said that the mean scores of the two groups before the experimental process were very close to each other. When the experimental group post-test mean scores were analyzed after the active listening training, it could be seen that the increase in vocabulary achievement levels of the experimental t group was significantly higher than the average score of the control group where this training was not given.

The change in the pre-test - post-test scores of the experimental and control groups is also shown in the figure below.

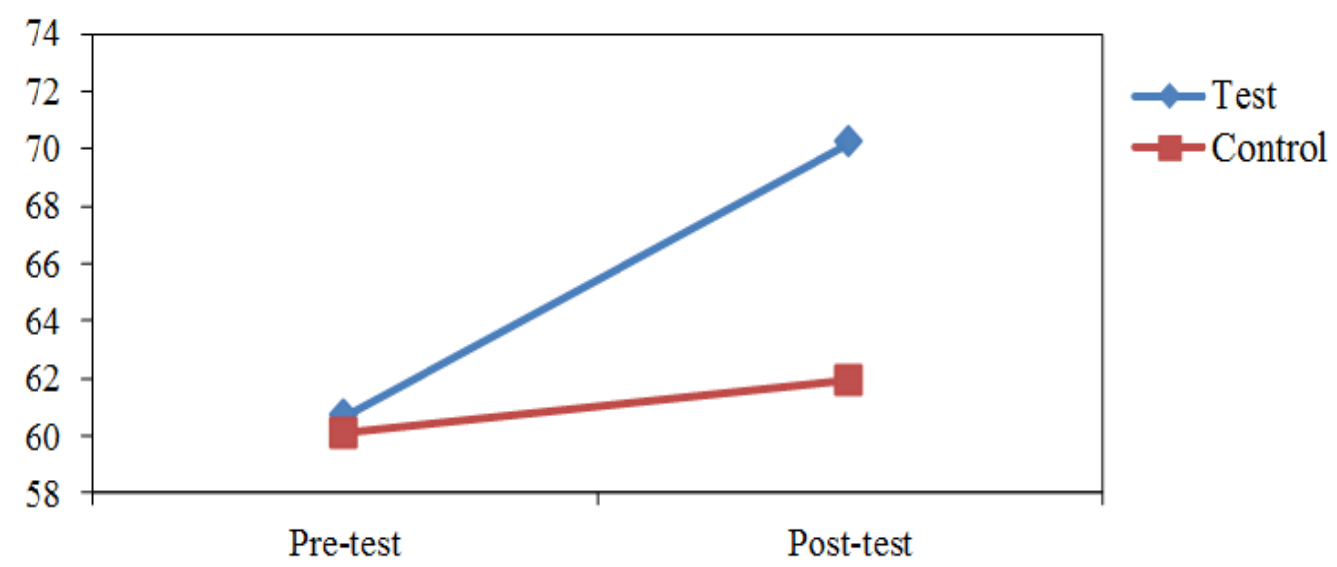

Figure 2. Vocabulary Change of Experimental and Control Groups 
When Figure 2 is examined, it can be said that of the two groups with mean scores very close to one another, the vocabulary test pre-test-post-test mean scores of the experimental group given active listening training showed a noticeable increase compared to the control group.

The results of the Two-Way ANOVA variance analysis for mixed measures of whether the change observed before and after the experimental process showed any significant difference in the vocabulary of the students in the experimental and control group are shown in Table 9.

Table 9. ANOVA Results of Vocabulary Test Pre-test - Post-test Scores

\begin{tabular}{cccccc}
\hline The Source of Variance & KT & Df & KO & F & p \\
\hline Between the Subjects & 56236.264 & 124 & & & \\
Group (Test/Control) & 1234.062 & 1 & 1234.062 & 2.76 & .099 \\
Error & 55002.202 & 123 & 447.172 & & \\
Within the Subjects & 22825.271 & 125 & & & \\
Measure (Pre-test - Post-test) & 2021.167 & 1 & 2021.167 & 12.51 & .001 \\
Group*Measure & $\mathbf{9 3 1 . 8 8 7}$ & $\mathbf{1}$ & $\mathbf{9 3 1 . 8 8 7}$ & $\mathbf{5 . 7 6}$ & $\mathbf{. 0 1 8}$ \\
Error & 19872.217 & 123 & 161.563 & & \\
Total & 79061.535 & 249 & & & \\
\hline
\end{tabular}

When the table was examined, it was concluded that the "Vocabulary Test" mean scores of the students in the test and control groups differed significantly after the experiment, that is to say, the common effects of the repeated measures factors on the vocabulary achievement levels were significant in the different treatment groups $[F(1,123)=5.76, p$ $<.05]$. In other words, the increase in the vocabulary achievement of the students in the experimental group was significantly higher than the increase in the achievements of the students in the control group. This finding indicated that the students in the experimental group gained more acquisitions in terms of vocabulary achievement after the test than the students in the control group and that active listening training had a positive effect on the vocabulary of the students. Accordingly, it can be said that vocabulary achievements made more progress in the experimental group than the control group, depending on the training given. From this aspect, it can be interpreted that listening, which is of the comprehension skills, contributes to learning new words from the outside world.

The other hypothesis of the research was stated as "The change in post-test "vocabulary test" scores of the students in the experimental group in which active listening training was given explains the post-test scores of "listening comprehension test" significantly".

Regression analysis was used in testing the research hypothesis. For this, whether the assumptions of the regression analysis were met or not was analyzed. First of all, whether the relationship between listening comprehension and vocabulary variables showed a linear characteristic was analyzed by scatter diagram. According to the results obtained, it can be said that listening comprehension and vocabulary variables had a positive linear relationship. On the other hand, the normality assumption of the dependent and independent variables in the hypothesis was investigated when the assumptions of the variance analysis were examined, and according to the findings obtained, it can be said that the vocabulary post-test mean scores were normally distributed. Besides, it can be stated that the mean scores of the experimental group "Listening Comprehension Test" post-test (Kolmogorov-Smirnov $Z=0.585, \mathrm{p}>.05$ ) showed normal distribution.

The results of the regression analysis related to what extent the change in the experimental group students' vocabulary achievements were affected by the increase in their listening comprehension achievements are given in the table below.

Table 10. The Results of Regression Analysis in Terms of Predicting Vocabulary Achievement

\begin{tabular}{cccccccc}
\hline Variable & $\mathbf{B}$ & $\begin{array}{c}\text { Standard } \\
\text { Error }_{\mathbf{B}}\end{array}$ & $\boldsymbol{\beta}$ & $\mathbf{t}$ & $\mathbf{p}$ & $\mathbf{R}$ & $\mathbf{R}^{\mathbf{2}}$ \\
\hline Constant & 14.405 & 12.800 & - & 1.125 & .265 & - & - \\
Listening & 0.777 & 0.176 & 0.496 & 4.426 & .000 & 0.496 & 0.246 \\
Comprehension & & & & & & & \\
Achievement & & & & & & \\
\hline $\mathrm{F}_{(1,60)}=19.591, \mathrm{p}=.000$ & & &
\end{tabular}

According to the results of the variance analysis given in Table 10, it can be stated that the relationship between the dependent and independent variables was linear and that the regression model in terms of the relationship mentioned was significant $[\mathrm{F}(1,60)=19.591, \mathrm{p}<.01]$. On the other hand, when the results of the $\mathrm{t}$-test on the significance of the regression coefficients were examined, it could be seen that listening comprehension achievement significantly explained the change in vocabulary achievement $(\mathrm{p}<.01)$. It can also be said that about $25 \%$ of the total variance related to vocabulary achievement was explained by the students' listening comprehension achievements. According to these findings, depending on the effective listening training given to the students in the experimental group, it can be interpreted that the change in the students' vocabulary achievements were affected by the increase in their listening 
comprehension achievements. According to this, it can be said that the students' learning comprehension achievements contribute to learning of new words.

\section{Conclusion and Discussion}

In this section, the results obtained from the research findings are presented and the results obtained in accordance with the related literature are discussed by comparing with similar studies.

Findings obtained as a result of the semi-experimental study revealed that active listening training was effective in improving the vocabulary of the students in the experimental group. In other words, the analyses performed showed that the difference between the increase in the vocabulary achievements of the students in the experimental group and the increase in the vocabulary achievements of the students in the control group was statistically significant on behalf of the experimental group. It can be concluded from this finding that making experimental group students be aware of the new vocabulary they hear and giving them the opportunity to use these words in different settings improves the vocabulary of the students.

The views and the findings mentioned in the related literature support this conclusion of the research.

Göğüş, (1983) states that the child begins to learn his/her mother tongue by listening to it from the family and the surrounding, by recognizing and telling the names of certain beings, the words that are attributed to these actions and qualities; and this knowledge and skill of the individual increases, together with the development of the mind, with the words and terms from the information learned at school. The National Institute of Child Health and Human Development (NICHD, 2000, cited by Yıldırım, 2010) emphasizes the importance of reading and listening activities plentifully in the vocabulary teaching process. Temur (2006) states that it is possible to improve the vocabulary of the students through listening in class.

In a study conducted on their fourth grade students, Hawkins, Musti-Rao, Hale, McGuire, and Hailley (2010) analyzed the emerging change in the students' reading comprehension and vocabulary achievements by using a pre-reading listening strategies. As a result, it was observed that by using the listening strategies, there was an increase in the reading comprehension and vocabulary achievements of the students in the experimental group.

Hilman (1975, cited by Joly, 1980) notes that hearing words in the text enhances the vocabulary of the listeners. It is also stated that one of the acquisitions of careful listening is learning new words indirectly (Robertson, 1997). Çeçen (2007) argues that children should learn the new words in natural means as they learn the words in the spoken language by listening in natural means.

One of the findings obtained as a result of the research is that the change in the students' vocabulary due to the active listening training given to experimental group students is significantly explained by their listening comprehension achievements. According to this, it can be concluded that the students' listening comprehension abilities contribute to learn new words.

Chall (1987, cited by Akyol, 1998) states that a child of around nine years old can not only pronounce about 10,000 words accurately by speaking and listening but also know the meanings of them. According to Ar1 (2010), a person's word acquisition occurs through listening and reading. Tosunoglu (1999) also states that children learn new words by listening.

Yalçın and Ozek (2006) state that listening has a positive effect on vocabulary development and claim that the data received from the external world during listening do not only add new words and concepts to the vocabulary but also prevent them from being deleted from the memory by providing a repetition of the existing words.

Vidal (2003) emphasizes that listening comprehension serves vocabulary acquisition. However, she also states that when compared to reading comprehension, the words acquired are fewer (Vidal, 2011).

Wise, Sevcik, Morris, Lovett, and Wolf (2007) found by the model they constructed using of structural equality model in a study that listening comprehension was a significant predictor of word recognition skill.

\subsection{Suggestions}

The suggestions prepared in the light of the findings obtained from this research in which the effect of active listening training given to the fourth grade students on their vocabulary was analyzed are presented below.

1. Bearing in mind that listening training starts in the family, educational work on the importance and development of this skill should be given to parents.

2. Thinking that any development in the language skills may affect others, teachers should give importance to all the learning areas of Turkish language equally.

3. Studies can be conducted about especially what the listening obstacles of the students in the classroom are, and what can be done to overcome these obstacles.

4. There should also be elective courses on listening training in classroom teaching departments. 


\section{References}

Akyol, H. (1998). Word recognition and effect to reading. VII. National Educational Sciences Symposium, Selçuk University, 1, 677-684.

Arı, G. (2010). Listening/Watching teaching. In C. Y1ldı (Eds.), According to new curriculum turkish education (pp. 179-202). Ankara: Pegem Akademi Yayınc1lk.

Büyüköztürk, Ş. (2011). The handbook of data analysis for social sciences (14 ${ }^{\text {th }}$ edition). Ankara: Pegem Akademi Publications.

Çeçen, M. A. (2007). Critical issues in vocabulary development. Journal of Turkish Linguistics, 1(1), 116-137.

Doğan, Y. (2011). Listening education. Ankara: Pegem Akademi Publications.

Ergin, A., \& Birol, C. (2000). Communication in education. Ankara: Anı Publications.

Gay, L. R., Mills, G. E., \& Airasian, P. (2005). Educational research: Competencies for analysis and application $\left(8^{\text {th }}\right.$ edition). Upper Saddle River, NJ: Pearson Education.

Göğüş, B. (1983). The nature of the mother tongue education program. Türk Dili, 40(43), 379-380.

Güleryüz, H. (1998). Programmed literacy teaching, theory and practices. Ankara: Pegem Publications.

Hawkins, O. R., Musti-Rao, S., Hale, A. D., Mcguire, S., \& Hailley, J. (2010). Examining listening previewing as a classwide strategy to promote reading comprehension and vocabulary. Psychology in the Schools, 47(9), 903-916. https://doi.org/10.1002/pits.20513

Jolly, T. (1980). Reading, writing, listening, speaking. Language Arts, 57(6), 664-668.

Karakuş, İ. (2002). Turkish language and literature training. Ankara: Anttepe Publications.

Koçak, H. (1999). The vocabulary knowledge of the students of health high school. Unpublished master's thesis, Gazi Univsersity, Ankara.

MEB. (2009). Primary education turkish curriculum. Ankara: MEB Publications.

Özbay, M. (2005). Listening education as a language skill. Ankara: Akçağ Publications.

Robertson, A. K. (1997). Listen for success. New York: Irwin Professional Publishing.

Schwartz, D. (1995). Ready, set, read - 20 minutes each day is all you'll need. Smithsonian, 25(11), 82-91.

Sever, S. (2011). Turkish training and ve mastery learning ( $5^{\text {th }}$ edition). Ankara: An1 Publications.

Temur, T. (2006). The examination of the 4th and the 5th grade students' selections of vocabulary items in the process of writing with respect to some variables. Unpublished doctoral dissertation, Gazi Univsersity, Ankara.

Tosunoğlu, M. (1999). Importance of vocabulary in education. Milli Eğitim Dergisi, (144). Accessed from http://dhgm.meb.gov.tr/yayimlar/dergiler/Milli_Egitim_Dergisi/144/tosunoglu.htm.

Vidal, K. (2003). Academic listening: a source of vocabulary acquisition? Applied Linguistics, 24(1), 56-89. https://doi.org/10.1093/applin/24.1.56

Vidal, K. (2011). A comparison of the effects of reading and listening on incidental vocabulary acquistion. Language Learning, 61(1), 219-258. https://doi.org/10.1111/j.1467-9922.2010.00593.x

Wise, C. J., Sevcik, R. A., Morris, R. D., Lovett, M. W., \& Wolf, M. (2007). The relationship among receptive and expressive vocabulary, listening comprehension, pre-reading skills, word identification skills and reading comprehension by children with reading disabilities. Journal of Speech, Language and Hearing Research, 50, 1093-1109. https://doi.org/10.1044/1092-4388(2007/076)

Yalçı, S. K., \& Özek, F. (2006). Effects of vocabulary on acquaring basic language skills and academic disciplines. Milli Eğitim Dergisi, 35(171), 130-140.

Yıldırım, K. (2010). The effects of cooperative learning on certain variables related to reading, parents', and studens' opinions toward cooperative learning. Unpublished doctoral dissertation, Gazi Univsersity, Ankara.

\section{Copyrights}

Copyright for this article is retained by the author(s), with first publication rights granted to the journal.

This is an open-access article distributed under the terms and conditions of the Creative Commons Attribution license which permits unrestricted use, distribution, and reproduction in any medium, provided the original work is properly cited. 